\title{
Tu Chinese
}

National Cancer Institute

\section{Source}

National Cancer Institute. Tu Chinese. NCI Thesaurus. Code C158186.

A Chinese person from the Tu ethnic group. 